\title{
Analisis Kelayakan Ekonomi Mesin Pencacah Rumput Gajah Tipe Reel
}

\author{
Wahyu K Sugandi*, dan Asep Yusuf \\ Departemen Teknik Pertanian dan Biosistem, \\ Fakultas Teknologi Industri Pertanian Universitas Padjadjaran \\ *Alamat korespondensi : sugandiwahyu@gmail.com
}

\begin{abstract}
Economic analysis reel type cutting machine for elephant grass

The need grass for fodder in the region Lembang has been increasing, but it does not followed by its quality. Therefore, cutting machine which is able to cut the fodder no more than $5 \mathrm{~cm}$ size is needed. The Laboratory of Agricultural Machinery and Machinery Department of Agricultural Engineering and Biosystem FTIP Unpad had been developed an elephant grass enchant machine in accordance with the requirements of making the silage, but no economic feasibility analysis has been done for the machine. Therefore it was necessary to study the economic feasibility analysis of elephant grass cutting machine. The method used in this study was the economic analysis method which includes the cost of production and the breakeven point, and business feasibility including net present value (NPV), benefit cost ratio analysis (BCR), internal rate of return (IRR) and payback period analysis (PBP). The results showed that the cost of production of elephant grass enemies was Rp 2,178 / kg with production breakeven $18.769 \mathrm{~kg}$, BC ratio of 1.15, NPV1 of Rp 70,770, - NPV2 of Rp 61.333, - IRR of 27\% and payback period during 2 months. So it can be concluded that the use of elephant-type elephant chopper machine was feasible to use.
\end{abstract}

Keywords: Elephant grass, economic analysis, cutting machine

\begin{abstract}
ABSTRAK
Kebutuhan rumput gajah untuk pakan ternak (silase) di daerah Lembang terus meningkat. Syarat pembuatan silase tersebut bahwa panjang potongan rumput gajah sebaiknya $<5 \mathrm{~cm}$. Untuk itu diperlukan sebuah mesin pencacah rumput gajah sesuai syarat pembuatan silase. Laboratorium Alat dan Mesin Pertanian Departemen Teknik Pertanian dan Biosistem FTIP Unpad telah mengembangkan sebuah mesin pencacah rumput gajah sesuai syarat pembuatan silase tersebut, tetapi belum dilakukan analisis kelayakan ekonomi untuk mesin tersebut. Oleh karena it diperlukan suatu penelitian berkenaan dengan analisis kelayakan ekonomi mesin pencacah rumput gajah. Metode yang digunakan pada penelitian ini adalah metode analisis ekonomi yang meliputi biaya pokok produksi dan titik impas, serta kelayakan usaha yang meliputi net present value (NPV), benefit cost ratio analysis (BCR), internal rate of return (IRR) dan payback period analysis (PBP). Hasil penelitian menunjukkan bahwa biaya pokok produksi mesin pencacah rumput gajah adalah Rp 2.178/kg dengan titik impas produksi $18.769 \mathrm{~kg}$, BC rasio sebesar 1,15, NPV1 sebesar Rp $70.770,-\mathrm{NPV}_{2}=\mathrm{Rp}$ 61.333,- IRR sebesar 27\% dan payback period selama 2 bulan. Maka dapat disimpulkan bahwa pengunaan mesin pencacah rumput gajah tipe reel layak digunakan.
\end{abstract}

Kata Kunci : Rumput Gajah, Analisis Ekonomi, Mesin Pencacah

\section{PENDAHULUAN}

Hijauan makanan ternak (forages) merupakan pakan utama ternak serta merupakan dasar dalam usaha pengembangan peternakan terutama untuk ternak ruminansia termasuk didalamnya sapi perah, sapi potong (pedaging) (Hidayat dkk., 2006). Untuk meningkatkan 
produktivitas ternak, salah satu faktor penting yang harus diperhatikan adalah penyediaan pakan hijauan (Farizaldi, 2011). Pakan tersebut harus tersedia sepanjang tahun dengan kualitas dan kuantitas yang cukup agar pemenuhan kebutuhan zat-zat makanan ternak untuk mempertahankan kelestarian hidup dan keutuhan alat tubuh ternak (kebutuhan hidup pokok) dan tujuan produksi (kebutuhan produksi) dapat berkesinambungan (Strur \& Horne, 1999). Hal ini dimungkinkan bila kita mampu mengelola strategi penyediaan pakan hijauan baik rumput maupun legum.

Indonesia, dengan kondisi iklim dan tanah yang subur, membuat peternak tidak pernah memikirkan dan merencanakan penyediaan pakan hijauan yang cukup baik kualitas maupun kuantitasnya. Sebagian besar peternak membudidayakan peterneaknya secara tradisional dengan melepas hewan ternaknya di lahan-lahan rumput (Jarmani \& Haryanto, 2015). Keterbatasan lahan untuk penanaman hijauan merupakan kendala bagi peternak. Disamping itu para peternak belum mengupayakan lahan kebun rumputnya dikelola secara baik dan efektif sehingga produktivitasnya belum optimal.

Produksi dari kebun rumput bila dipelihara secara optimum pada bulan basah akan menghasilkan hijauan yang maksimum, tetapi hasil ini perlu ditangani secara baik dan benar untuk dijadikan cadangan pada musim kemarau, sehingga dapat memenuhi kebutuhan hijauan untuk ternaknya baik secara kuantitas maupun kualitas. Hal ini dapat dilakukan jika sistem pengelolaan penyediaan hijauan dari pemotongan kemudian pencacahan dan diberikan langsung kepada ternak atau disimpan terlebih dahulu di gudang hijauan baru diberikan kepada ternak. Perubahan ini tidak mudah tetapi jika dicoba akan memberikan hasil yang efisien dan efektif dengan memfungsikan gudang pakan sebagai sentral manajemen pakan. Pada lingkup gudang pakan inilah perencanaan pakan peternak bermula, dari mulai panen hijauan hingga prosesing hijauan untuk persediaan dimusim sulit pakan. Salah satu sistem pengelolaan penyediaan hijauan adalah dengan cara pembuatan silase.

Silase adalah pakan yang telah diawetkan yang diproduksi atau dibuat dari tanaman yang dicacah, pakan hijauan, limbah dari industri pertanian dan lain-lain dengan kandungan air pada tingkat tertentu yang diisikan dalam sebuah silo (Hidayat, 2014). Salah satu syarat dalam pembuatan silase adalah hijauan dalam hal ini adalah rumput gajah telah tercacah dengan baik dengan ukuran 1 $5 \mathrm{~cm}$ setelah itu lalu dimasukkan kedalam silo yang dicampurkan dengan dedak dalam kondisi anaerob selama 21 hari untuk proses fermentasi.

Data yang diperoleh dari Perum Perhutani KPH Bandung Utara pada bulan Desember 2011 kebutuhan hijauan makanan ternak mencapai 600 ton/hari. Kebutuhan ini merupakan kebutuhan para peternak sapi yang tergabung dalam Koperasi Peternak Sapi Bandung Utara (KPSBU). Mengingat besarnya kuantitas rumput yang akan dicacah, kegiatan pencacahan hanya mungkin dilakukan dengan mekanisasi.

Spesifikasi mesin pencacah juga harus memenuhi kebutuhan dan kondisi peternak sapi yang ada di Indonesia. Beberapa penelitian yang berhubungan dengan pencacahan seperti mekanisme pemotong rumput tipe rotary (Kahar, 2018)), rancang bangun perajang tembakau (Pitrandjalisari \& Putra, 2014), alat pencacah kompos (Hendaryanto, 2018), pemotongan pelepah dan tandan sawit (Christian dkk., 2018)) telah dilakukan tetapi penelitian yang khusus mengenai pencacah rumput gajah dengan menggunakan pisau tipe reel belum ada.

Sugandi (2012) melaporkan bahwa karakteristik fisik dari rumput gajah hasil pengukuran diperoleh data sebagai berikut: rata rata panjang daun $99,4 \mathrm{~cm}$, lebar daun $2,65 \mathrm{~cm}$, tebal daun $0,23 \mathrm{~cm}$, berat daun 7,8 gram, kerapatan isi (bulk density) rumput gajah adalah $157 \mathrm{~kg} / \mathrm{m}^{3}$ dengan kadar air bahan $81,1 \%$, dimensi mesin pencacah adalah panjang $800 \mathrm{~mm}$, lebar $750 \mathrm{~mm}$ dan tinggi 1042, jumlah pisau sebanyak 8 buah, sistem transmisi menggunakan belt dan puli dengan ratio reduksi 1 : 1,4 dari motor penggerak ke unit pencacah, kapasitas mesin adalah $1988 \mathrm{Kg} / \mathrm{jam}$, daya yang dibutuhkan untuk mencacah serasah tebu adalah 1,6 kW, tingkat getaran mesin 18,23 mm/s tingkat kebisingan mesin $78,11 \mathrm{~dB}$, panjang rata rata pemotongan yang dihasilkan antara $1-3 \mathrm{~cm}$. Hasil aplikasi mesin pencacah rumput gajah ini tentunya perlu penilaian kelayakan ekonomi. Nilai investasi dikoreksi dengan dengan menggunakan faktor lokasi dan kemampuan rancang bangun mesin pencacah rumput gajah. Tujuan dari penelitian ini adalah menganalisis ekonomi mesin pencacah rumput gajah tipe reel.

\section{BAHAN DAN METODE}

\section{Metode Analisis Ekonomi}

Analisis ekonomi dilakukan melalui perhitungan untuk mengetahui apakah mesin 
pencacah rumput gajah gajah ini layak secara ekonomi. Analisis ekonomi dihitung berdasarkan biaya yang dikeluarkan dalam proses pencacahan rumput gajah. Tahapan analisis ekonomi mesin pencacah rumput gajah ini meliputi; analisis biaya pokok pengoperasian mesin, besarnya penerimaan, penentuan titik impas usaha atau break event point (BEP) dan analisis kelayakan finansial ekonomi dengan menggunakan Metode Ekivalensi Nilai Sekarang atau Net Present Value (NPV), Metode Tingkat Suku Bunga Pengembalian Modal atau Internal Rate of Return (IRR), Metode Rasio Manfaat dan Biaya (BCR) dan Metode pengembalian modal atau Pay Back Period (PBP).

\section{Biaya Produksi}

Biaya produksi dilihat dari biaya yang dikeluarkan secara langsung, meliputi biaya tetap (fixed cost) dan biaya variabel (variable cost) selama satu periode produksi. Biaya tetap terdiri dari biaya manajemen, biaya sewa lahan, biaya penyusutan, bunga modal, dan pajak. Biaya variabel terdiri dari bahan baku, bahan bakar, dan biaya lainnya yang berubah sesuai volume produksi. Biaya total dapat dihitung dengan menjumlahkan biaya tetap total dan biaya variabel total sesuai dengan Persamaan (1) (Pramudya \& Dewi, 1992).

$\mathrm{BP}=\mathrm{BT}+\mathrm{BV}$

Dengan :

$\mathrm{BP}=$ biaya produksi (Rp/tahun)

$\mathrm{BT}=$ biaya tetap $(\mathrm{Rp} / \mathrm{tahun})$

$\mathrm{BV}=$ biaya variabel (Rp/tahun)

\section{Biaya Tetap}

Biaya tetap adalah biaya yang harus dikeluarkan secara tetap pada periode waktu yang besarnya tidak dipengaruhi oleh besar kecilnya volume operasi atau volume produksi (Kastaman, 2001). Komponen biaya tetap dalam pengoperasian mesin pencacah rumput gajah terdiri dari:

\section{Biaya penyusutan}

Biaya penyusutan adalah biaya yang secara periodik harus dikeluarkan sebagai konsekuensi atas penurunan kinerja mesin. Besarnya biaya penyusutan dapat dihitung menggunakan persamaan berikut (Kastaman, 2001):

$\mathrm{D}=\frac{P-S}{N}$

Keterangan:

$$
\mathrm{D} \text { = Biaya penyusutan (Rp/tahun) }
$$

$$
\begin{aligned}
& \mathrm{P}=\text { Harga mesin (Rp) } \\
& \mathrm{S}=\text { Nilai akhir mesin (Rp) } \\
& \mathrm{N}=\text { Umur mesin (tahun) }
\end{aligned}
$$

\section{Biaya Perbaikan dan Pemeliharaan}

Biaya perbaikan dan pemeliharaan adalah biaya yang secara periodik harus dikeluarkan untuk memperbaiki komponen mesin yang rusak (RNAM, 1995). Perhitungan rata-rata biaya perbaikan dan pemeliharaan mesin per tahun dapat dihitung melalui persamaan berikut:

$\mathrm{R}=P \times \frac{m}{100}$

Keterangan:

$\mathrm{R}=$ Biaya perawatan dan perbaikan

(Rp/tahun)

$\mathrm{P}=$ Harga mesin $(\mathrm{Rp})$

$\mathrm{m}$ = Presentase rata-rata biaya perawatan dan perbaikan

\section{Bunga Modal}

Bunga modal adalah manifestasi uang berdasarkan nilai waktunya. Perhitungan bunga modal mengharuskan peminjam membayar lebih besar dari peminjaman awal. Pembayaran dilakukan periodik sesuai lamanya pinjaman Perhitungan bunga modal menurut RNAM (1995) dapat menggunakan persamaan berikut:

$\mathrm{I}=\frac{p-S}{2} \times r$

Keterangan :

I = Bunga modal (Rp/tahun)

$\mathrm{r} \quad=$ Suku bunga bank (\%/tahun)

$\mathrm{P} \quad=$ Harga mesin (Rp)

$\mathrm{S} \quad=$ Nilai akhir $(\mathrm{Rp})$

Biaya tetap per tahun dihitung dengan menggunakan persamaan berikut:

$\mathrm{BT}=\mathrm{D}+\mathrm{R}+\mathrm{I}$.

Keterangan :

$\mathrm{BT}=$ Biaya tetap (Rp/tahun)

$\mathrm{D}=$ Biaya penyusutan ( $\mathrm{Rp} /$ tahun)

$\mathrm{R}=$ Biaya perbaikan dan perawatan (Rp/tahun)

$\mathrm{I}=$ Bunga modal (Rp/tahun)

\section{Biaya Tidak Tetap}

Biaya tidak tetap dapat diartikan sebagai biaya yang berhubungan langsung dengan produksi karena besarnya ditentukan oleh berapa besar volume produksi yang dilakukan. Biaya tidak tetap per tahun dari mesin ini dapat dihitung menggunakan persamaan berikut:

$\mathrm{BTT}=(\mathrm{BL}+\mathrm{BO})$ 
Keterangan:

BTT = Biaya tidak tetap $(\mathrm{Rp} / \mathrm{hari})$

$\mathrm{BL} \quad=$ Biaya listrik (Rp/hari)

$\mathrm{BO}=$ Biaya operator $(\mathrm{Rp} / \mathrm{hari})$

\section{Penentuan Titik Impas Usaha (Break Even Point} $(B E P))$

Titik impas usaha (BEP) adalah suatu kondisi dimana besarnya pendapatan dari penjualan produk akan sama dengan besarnya total pengeluaran (Blank \& Tarquin, 2002). Perhitungan titik impas usaha meliputi perhitungan biaya pokok (Biaya tetap dan biaya tidak tetap) dan harga jual jasa.

$\mathrm{BEP}=\frac{B T}{H p-B V}$

Keterangan :

BEP = Titik impas usaha (kg/tahun)

BT = Biaya tetap (Rp/tahun)

$\mathrm{Hp} \quad=$ Harga jual produk $(\mathrm{Rp} / \mathrm{kg})$

$\mathrm{BV} \quad=$ Biaya tidak tetap $(\mathrm{Rp} / \mathrm{kg})$

\section{Analisis Kelayakan Finansial Ekonomi}

Metode Ekivalensi Nilai Sekarang (Net Present Value (NPV))

Metode Ekivalensi Nilai Sekarang (Net Present Value/NPV) merupakan cara mengubah besarnya nilai uang pada waktu mendatang menjadi waktu nilai di waktu sekarang. Suatu usaha dinyatakan layak jika nilai NPV > 0 (Blank \& Tarquin, 2002). NPV dapat dihitung menggunakan persamaan berikut:

$\mathrm{NPV}=\sum \mathrm{PV}_{\text {pendapatan }}-\sum \mathrm{PV}$ pengeluaran ......(8)

Rasio Manfaat dan Biaya (Benefit Cost Ratio (BCR))

$\mathrm{B} / \mathrm{C}$ ratio atau rasio manfaat dan biaya adalah perbandingan antara nilai sekarang (PV) pendapatan (Benefit) dengan nilai sekarang (PV) pengeluaran (Cost) (Thuessen \& Fabrycky, 1993). Apabila Net $B / C>1$ proyek dianggap layak, Net $B / C$ $>1$ merupakan titik impas dan bila $N e t B / C<1$ maka proyek dinyatakan tidak layak. $B / C$ ratio dapat dihitung dengan menggunakan persamaan berikut:

$\mathrm{BCR}=\frac{\sum \text { PV pendapatan }}{\sum \text { PV pengeluaran }}$

\section{Tingkat Suku Bunga Pengembalian Modal (Internal Rate of Return (IRR))}

IRR adalah tingkat suku bunga yang dapat menyamakan penerimaan pada cash flow dengan pengeluaran pada cash flow tersebut. Perhitungan
IRR dilakukan secara trial and error (mencoba coba) hingga didapatkan suku bunga yang menyebabkan NPV di bawah nol (Thuessen \& Fabrycky, 1993). Kriteria kelayakan finansial untuk IRR adalah apabila IRR > MARR atau suku bunga bank (Blank \& Tarquin, 2002). IRR dapat dihitung menggunakan persamaan berikut:

$\mathrm{IRR}=\mathrm{i}_{1}-\mathrm{NPV} 1 \frac{\left(i_{2}-i_{1}\right)}{N P V_{2}-N P V_{1}}$

Keterangan:

$i_{1} \quad=$ Suku bunga kesatu (\%)

i $_{2}=$ Suku bunga kedua (\%)

$\mathrm{NPV}_{1}=\mathrm{NPV}$ pada suku bunga $i_{1}(\mathrm{Rp})$

$\mathrm{NPV}_{2}=\mathrm{NPV}$ pada suku bunga i2 $(\mathrm{Rp})$

\section{Pay Back Period (PBP)}

Tingkat pengembalian investasi diartikan sebagai jangka waktu kembalinya investasi yang dikeluarkan melalui keuntungan yang diperoleh dari suatu proyek. Menghitung Pay back Peroid tidak perlu memperhitungkan tingkat bunga dan Net Present Value dengan menggunakan discount factor.

Penghitungan Pay back Period hendaknya dilakukan setelah menghitung IRR dan kriteria investasi lainnya. Semakin cepat tingkat pengembalian investasi maka proyek layak untuk diusahakan dan sebaliknya semakin lambat investasi yang digunakan itu dikembalikan maka proyek tidak layak untuk diusahakan.

\section{HASIL DAN PEMBAHASAN}

\section{Analisis Ekonomi}

Analisis ekonomi digunakan untuk menghitung biaya-biaya yang dikeluarkan dalam pembuatan suatu produk baik biaya tetap maupun biaya tidak tetap, dengan menggunakan data biaya dari penelusuran pustaka, dan survei lapangan. Analisis ekonomi menghitung biaya pokok, titik impas usaha $(B E P)$ dan analisis kelayakan finansial ekonomis. Pengembangan usaha pembuatan silase dapat di golongkan ke dalam perencanaan suatu kegiatan untuk mendapatkan keuntungan dengan memanfaatkan sumber daya yang ada.

Berdasarkan Bank Rate bulan November 2016 yang digunakan dalam analisis ekonomi untuk penghitungan biaya tetap adalah tingkat suku bunga bank per tahun sebesar $12 \%$, umur ekonomis alat selama 5 tahun, nilai rongsok mesin 10\% dari harga mesin, biaya perawatan dan perbaikan sebesar $8 \%$ dari harga mesin, asuransi $1 \%$ dari harga mesin. Survei lapangan untuk penghitungan biaya tidak 
tetap adalah kebutuhan energi listrik (kwh), upah operator per jam. Survei pasar yang akan digunakan adalah dalam satu kali pembelian silase sebagai bahan baku yang diproses.

Analisis biaya pokok produksi didapat dengan penjumlahan nilai keseluruhan dari biaya tetap dan biaya tidak tetap. Hasil perhitungan dari biaya pokok mesin pencacah rumput gajah per tahunnya adalah sebesar Rp. 47.487.040/ tahun, untuk pendapatan kotor dalam 1 tahun sebesar Rp. 1.908.480.000/ Tahun. Nilai dari biaya pokok dan penerimaan kotor dalam satu tahunnya akan digunakan dalam perhitungan titik impas usaha (BEP), dan analisis finansial ekonomi (NPV,BC/R,IRR dan Pay Back Period).

Nilai dari biaya pokok merupakan penjumlahan dari biaya tetap (Fix Cost) dan biaya tidak tetap (Variable Cost). Nilai dari biaya tetap sebesar Rp. 6.280.000,-/Tahun dan biaya tidak tetap sebesar Rp. 41.207.040,-/Tahun. Biaya tetap meliputi biaya penyusutan, biaya perawatan, biaya modal, Biaya tidak tetap meliputi biaya gaji operator dan biaya konsumsi energi listrik. Pendapatan kotor didapatkan berdasarkan nilai kapasitas kerja mesin $\mathrm{x}$ jam operasi kerja/tahun $\mathrm{x}$ ongkos kerja. Kapasitas kerja mesin $1988 \mathrm{~kg} / \mathrm{jam}$, jumlah operasi kerja/tahun 1920 jam/tahun dan jasa pencacahan Rp. 500/kg.

Titik impas usaha (BEP) berdasarkan perhitungan jumlah produksi pencacahan rumput gajah dalam satu tahun. Titik impas usahan (BEP) dicapai setelah mesin pencacahan rumput gajah melakukan pencacahan sebanyak $12.837 \mathrm{~kg}$ sehingga titik impas usaha per tahunnya adalah 0,003 tahun.

\section{Analisis Kelayakan Finansial Ekonomi}

Analisis kelayakan finansial ekonomi dapat dilakukan dengan tiga metode yaitu, $N P V$ (Net Present Value), IRR (Internal Rate of Return), BCR (Benefit Cost Ratio).

\section{NPV (Net Present Value)}

Proses penacacahan untuk rumput gajahn dilihat dari nilai $N P V$ dinyatakan layak karena $N P V_{1}$ dan $N P V_{2}$ pengupasan bernilai positif yaitu sebesar Rp. 70.770,- dan Rp 61.333,- sehingga memenuhi kelayakan ekonomi $N P V \geq 0$ (Blank \& Tarquin, 2002). Nilai $N P V$ yang bernilai positif disebabkan $B E P$ yang tercapai pada tahun pertama. Kondisi tersebut menyebabkan nilai pendapatan sekarang lebih besar dari nilai pengeluaran sekarang selama lima tahun masa mesin pencacah rumput gajah sehingga nilai akhir $N P V$ bernilai positif. .

\section{IRR (Internal Rate of Return)}

IRR (Internal Rate of Return) adalah suatu tingkat discount rate yang menghasilkan Net Present Value sama dengan 0 (nol). Kelayakan ekonomi untuk IRR menurut (Blank \& Tarquin, 2002) nilai suku bunga $I R R \geq M A R R$ per suku bunga bank. Hasil perhitungan dari IRR sebesar $27 \%$, sedangkan nilai dari $M A R R$ sendiri yang digunakan adalah 12,5 \% (suku bunga bank, 2016). Proses dari pencacahan mesin pencacah rumput gajah memenuhi kelayakan ekonomi untuk IRR.

\section{$B / C$ Ratio}

Benefit Cost Ratio merupakan perbandingan antara pendapatan yang diperoleh dengan biaya produksi yang dikeluarkan. Persyaratan kelayakan $B / C$ ratio jika nilai $B / C$ ratio $\leq$ 1, maka proses produksi tidak layak untuk dilakukan karena perusahaan mengalami kerugian. Sebaliknya jika nilai $B / C$ ratio $\geq 1$ maka proses produksi (usaha) tetap dapat dijalankan karena perusahaan mendapatkan keuntungan.

Jika $B / C$ ratio sama dengan 1 maka perusahaan mengalami titik impas (tidak untung tidak rugi). Sedangkan penghitungan $B / C$ ratio dari proses pencacahan sebesar 1,15 nilai tersebut sudah memenuhi kelayakan ekonomi $B / C$ ratio dan menunjukan bahwa usaha tersebut mempunyai keuntungan (benefit) lebih besar dari biaya produksi $(\cos t)$.

\section{SIMPULAN}

Biaya pokok mesin pencacahan rumput gajah senilai $\mathrm{Rp}$ 47.487.040/tahun, atau setara dengan nilai $12,44 / \mathrm{kg}$. Per- hitungan titik impas produksi pencacahan rumput gajah adalah sebesar $12.837 \mathrm{~kg}$. . Berdasarkan analisis ekonomi mesin pencacah rumput gajah dapatkan $\mathrm{BC}$ rasio sebesar 1.15, NPV 1 = Rp 70.770,-, NPV1 Rp 61.333,-, IRR sebesar $27 \%$.

\section{DAFTAR PUSTAKA}

Blank, L. and A Tarquin. 2002. Engineering Economy. McGraw-HillCompanies, Inc. United State of America.

Christian, A, S Asmara, C Sugianti dan M Telaumbanua. 2018. Unjuk kerja alat pemotong pelepah sawit tipe dodos manual dan mekanis. Jurnal Teknik Pertanian Lampung 7 (1): 15-24.

Farizaldi. 2011. Produktivitas hijauan makanan ternak pada lahan perkebunan sawit 
berbagai kelompok umur di PTPN 6 Kabupaten Batanghari Propinsi Jambi. Jurnal Ilmiah Ilmu-ilmu Peternakan 14 (2): 68-73.

Heryanto, IA. 2018. Pembuatan mesin pencacah sampah organic untuk swadaya pupuk di Desa Tancep Kecamatan Ngawen Kabupaten GunungKidul. Jurnal Pengabdian dan Pengembangan Masyarakat 1 (1): 11-18.

Hidayat, M, Harjono, Marsudi, dan A Gunanto. 2006. Evaluasi kinerja teknik mesin pencacah hijauan pakan ternak. Jurnal Enjiniring Pertanian 4 (2): 61-64.

Hidayat, N. 2014. Karakteristik dan kualitas silase rumput raja menggunakan berbagai sumber dan tingkat penambahan karbohidrat fermentable. Agripet 14 (1): 42-49.

Jarmani, SN, dan B Haryanto. 2015. Memperbaiki produktivitas hijauan pakan ternak untuk menunjang kapasitas padang penggembalaan kerbau di Kabupaten Kampar, Riau (suatu saran pemikiran). Pastura 4 (2): 95-99.

Pramudya, B, dan N Dewi. 1992. Ekonomi Teknik. IPB. Bogor.
Kahar. 2018. Desain mesin pemotong rumput tipe rotary dengan mesin penggerak motor listrik. Jurnal Pertanian Terpadu 6 (2): 7678.

Kastaman, R. 2001. Ekonomi Teknik untuk Pengembangan Kewirausahaan. Pustaka Giratuna, Bandung.

Pitrandjalisari, V, dan TW Putra. 2014. Perancangan mesin peranjang tembakau menggunakan tiga mata pisau pada kapasitas $120 \mathrm{~kg} / \mathrm{jam}$. Widya Teknika 22 (1): 52-60.

Stur, WW and PM Horne. 1999. Mengembangkan teknologi hijauan makanan ternak bersama petani kecil : Cara menanam, mengelola, dan memanfaatkan HMT. ACIAR Monograph No. 65. Australian Centre for International Agricultural Research (ACIAR) dan Centro Internacional de Agricultura Tropical (CIAT).

Sugandi, WK. 2012. Rancang Bangun Mesin Pencacah Rumput Gajah dengan Menggunakan sitem Tipe Reel. Laporan Penelitian. LPPM Unpad.

Thuessen, GJ and WJ Fabrycky. 1993. Engineering Economy, $8^{\text {th }}$ Edition. Prentice Hall, New Jersey. 